\title{
IMPACT OF FERTILIZERS ON SOIL PROPERTIES IN THE CASE OF SOLANUM TUBEROSUM L. DURING CONVERSION TO ORGANIC FARMING
}

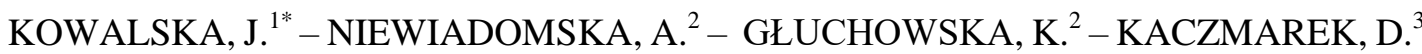 \\ ${ }^{I}$ Institute of Plant Protection- NRI, Department of Ecology and Environmental Protection \\ Wegorka 20, 60-318 Poznan, Poland \\ ${ }^{2}$ University of Life Sciences, Department of General and Environmental Microbiology \\ Szydtowska 50, 60-637 Poznan, Poland \\ (e-mail: alicja.niewiadomska@onet.eu,kasiaglu@up.poznan.pl) \\ ${ }^{3}$ Inspectorate of Plant Health and Seed Inspection \\ T. Kościuszki 15, 64-000 Kościan, Poland \\ (e-mail:dominikakaczmarek@tlen.pl) \\ *Corresponding author \\ e-mail: j.kowalska@iorpib.poznan.pl,phone: +48-61-864-9077 \\ (Received 24 $4^{\text {th }}$ Mar 2017; accepted $5^{\text {th }}$ Jul 2017)
}

\begin{abstract}
In organic farming the use of mineral fertilizers is highly restricted; hence biofertilizers are often used. The aim of the research was to investigate the effects of different fertilizers on soil microbial communities and enzymatic activity after conventional production. A field with potato cultivation under conversion to an organic system was established. The nitrogen organic fertilizer Bioilsa and two microbial biofertilizers - UGmax and EM - were used. The highest values of dehydrogenase activity (DHA) were observed in the soil where UGmax was used alone. Application of biofertilizers also caused an increase of DHA in variants with Bioilsa fertilizer. The differences in activity of phosphatase in relation to application of different biofertilizers were observed, but it was higher than in variants with Bioilsa. Application of Bioilsa had a positive effect on activity of acid and alkaline phosphatases, but probiotic EM reduced this positive effect. The total number of bacteria and actinobacteria was the highest in EM variants, not fertilized with Bioilsa. In the case of the fungal population no correlation with fertilization was noted. We conclude that biofertilizers can activate the microbial and enzymatic activity of the soil after intensive agriculture production and can neutralize the negative impact on these parameters of nitrogen fertilizer.
\end{abstract}

Keywords: biofertilizers, nitrogen organic fertilizer, soil microbiology, dehydrogenase activity, phosphomonoesterases

\section{Introduction}

Organic farming avoids application of synthetic fertilizers and pesticides, uses organic inputs, promotes recycling for nutrient supply and emphasizes cropping system design and biological processes for pest management (Le Guillou and Scharpé, 2001; Araújo et al., 2009). In the European Union, organic production of agricultural products is certified and regulated by Council Regulation 834/2007 (2007). During conversion to organic production there are in force restrictions on the use of mineral fertilizers and plant protection products that are subsequently maintained. The soil fertility can be improved only by establishing a rotation with legumes or large amounts of manure. This paper hypothesized that biofertilizers are helpful to restore microbial balance in the soil after intensive agriculture production. The aim of the study was to investigate the 
impact of biofertilizers and nitrogen organic fertilizer on soil microbial communities and soil chemical properties in a farm under conversion to organic production.

\section{Review of Literature}

The soil microbial community plays an important role in maintaining soil fertility in an organic agriculture system. The microbial fertilization is beneficial especially for organic farming under the condition that microorganisms are not genetically modified. Biofertilization (e.g. using microbial fertilizers) is now a very important method of providing plants with their nutritional requirements without having an undesirable impact on the environment (Yassin, 2002; Abd El-Malek, 2005; Abou El-Yazied and Sellim, 2007). This method of fertilization is one of the many factors which play an important role in activating the enzymatic and microbial properties of the soil. It is particularly important in the system of organic farming because healthy soil is a crucial factor for both healthy plants and high yield.

In an organic system production of some crops is problematic in regard to nutrients, particularly enzymatic nitrogen. One of them is potato cultivation, the fourth most important food crop of the world. Potatoes are the most common crop in the world and are grown all over the world, production in Europe accounting for approximately $40 \%$ of world production. However, potato production is steadily decreasing. In Poland organic potato production covers $4 \%$ of the area of total organic farmland. The use of microbiological bio-agents (also referred as 'biofertilizers') can enhance tuber yielding and chemical composition of the soil; it has been studied for some years (Trawczyński and Bogdanowicz, 2007). Many different biofertilizers are available on the market for agricultural use. The products are claimed to enhance plant growth and yields and to improve soil fertility, but often their microbial composition is not specified in detail, making it difficult for the users to evaluate the product and for scientists to prove its effectiveness (Schenck zu Schweinsberg-Mickan and Müller, 2009).

One from many available biofertilizers is UGmax and probiotic Effective Microorganisms (EM). EM are microbial inoculants promoting stimulation of plant growth and soil fertility in agriculture. It is not clear whether EM contain microorganisms that can act as plant growth-promoting microorganisms (PGPM) (Meyer et al., 2010). UGmax is a microbiological preparation composed of yeasts, lactic acid bacteria, photosynthetic bacteria, Azotobacter, Pseudomonas and Actinobacteria, as well as potassium. UGmax aims at improving physiochemical soil properties. It accelerates the decomposition of post-harvest residue and organic fertilizers, activates nutrients from minerals or insoluble compounds and improves water relations (Długosz et al., 2010). Thus, crops can use elements from mineral fertilizers more efficiently, which in turn allows farmers to lower mineral fertilization doses, consequently limiting the emission of harmful substances to surface waters. The positive effect on potato tuber yield volumes is also well known after biofertilizers (Zarzecka et al., 2011).

The use of microorganisms is a source of controversy. There is evidence in the literature of both their usefulness in agriculture (Sangakkara et al., 2011) and a lack of evidence (Mayer et al., 2008; Mayer et al., 2010; Martyniuk and Księżak, 2011; Martyniuk, 2011). These preparations contribute to the improvement of the biological activity of the soil, increasing the binding of free nitrogen from the air, reducing the erosion and loss of nutrients.

Unlike organic farming, conventional agriculture is largely dependent on intensive chemical inputs and has an important role in improving food productivity. However, 
organic farming is a sector which is able to secure the food needs for the growing number of consumers. It grew from $\$ 3.2$ billion in 2008 to $\$ 5.5$ billion in 2014 , demonstrating increased demand for organic products and opportunities for growth (http://www.ofrf.org/organic-faqs). Many studies from around the world have compared organic and conventional farming systems in terms of soil properties. According to them microbial activity and nitrogen mineralization rates were higher under organic production than under conventional production (Workneh and van Bruggen, 1994). Enhanced soil fertility and higher biodiversity found in organic plots may render these systems less dependent on external input (Mäder et al., 2002). Organic farming with compost amendment showed the best results in terms of microbial biomass carbon, nitrogen and phosphorus (CNP) (Amaral and Abelho, 2016). Organic farming has been shown to favor soil biota in comparison with intensive farming (Kallenbach and Grandy, 2011; Santos et al., 2012). Field soils in organic farms were also more productive than conventional fields, probably due to the beneficial effects on soil properties of long-term organic amendments. The soil under the organic agricultural system presents higher microbial activity and biomass and lower bulk density than the conventional agricultural system (Araújo et al., 2009). In this context the changes taking place in the soil during the conversion period and after microbial fertilizers treatments applied to speed up the restoration to homeostasis are very interesting. The reality of contemporary agriculture necessitates the search for products improving the development and yield of crops, which are distinguished by a strong consequential impact in the entire crop rotation. When diagnosing the influence of different agrotechnical and chemical factors, including fertilizers, on the state of soil, enzymatic and microbial activity are considered to be good indicators of the soil environment quality because of their high sensitivity and rapid reaction. Monitoring the pedosphere by means of methods based on enzymatic tests enables complex assessment of changes taking place in the soil environment as a result of fertilization (Niewiadomska et al., 2010; Notrcliff, 2002; Tian et al., 2009).

\section{Material and Methods}

\section{Study location and experimental designs}

In 2014-2015 in the Experimental Station of the Institute of Plant Protection - NRI (western part of Poland, Wielkopolska region) in Winna Góra $(52.2 \mathrm{~N} ; 17.4 \mathrm{E})$ the experiment was established with potato cultivation under the first (2014) and the second year (2015) of conversion to an organic system (Fig. 1). On each experimental field wheat was cultivated as a forecrop. The experiment was carried out on plots (size plot $100 \mathrm{~m}^{2}$ with randomized distribution) within the one big area. Due to the necessary rotation, experimental plots were changed in subsequent years, although they were located side by side and within the one big area under conversion to organic production. Type soil was classified as clay soil with classification III b. One potato cultivar was cultivated - Ditta. No manure fertilizer was used. During the experiments the weather conditions were noted (Table 1). 


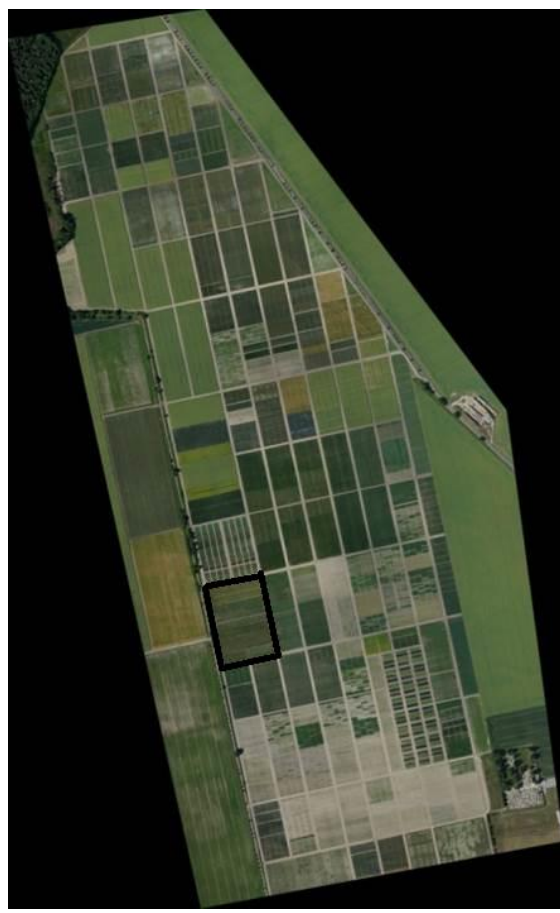

Figure 1. Map of experimental site, the black line indicates the field during conversion to organic farming

Table 1. Mean monthly values of selected weather parameters

\begin{tabular}{c|c|c|c|c|c|c}
\hline & \multicolumn{3}{|c|}{$\mathbf{2 0 1 4}$} & \multicolumn{2}{c}{$\mathbf{2 0 1 5}$} \\
\hline & $\begin{array}{c}\mathbf{T e m p} \\
\left({ }^{\circ} \mathbf{C}\right)\end{array}$ & $\begin{array}{c}\mathbf{R H} \\
(\boldsymbol{\%})\end{array}$ & $\begin{array}{c}\text { precipitation } \\
(\mathbf{m m})\end{array}$ & $\begin{array}{c}\mathbf{T e m p} \\
\left({ }^{\circ} \mathbf{C}\right)\end{array}$ & $\begin{array}{c}\mathbf{R H} \\
(\boldsymbol{\%})\end{array}$ & $\begin{array}{c}\text { precipitation } \\
(\mathbf{m m})\end{array}$ \\
\hline April & 11.0 & 74 & 40.6 & 8.7 & 69 & 1.2 \\
May & 13.9 & 75 & 119.3 & 13.7 & 69 & 7.3 \\
June & 16.8 & 73 & 41.7 & 16.5 & 72 & 32.5 \\
July & 22.0 & 69 & 71.9 & 20.0 & 67 & 13.6 \\
August & 18.0 & 75 & 58.8 & 22.8 & 58 & 0.0 \\
September & 15.8 & 81 & 61.4 & 15.6 & 73 & 4.6 \\
\hline
\end{tabular}

In the experiment organic nitrogen fertilization delivered by Bioilsa was used as the first research variant. The second research variant consisted of two biofertilizers, approved for organic plant production, probiotic EM (ProBiotics Polska) and UGmax (PPHU "Bogdan"), applied at a dose of 401 and $11 \mathrm{ha}^{-1}$, respectively. Effective microorganisms (EM) were a mixed culture of beneficial microorganisms including a predominant population of lactic acid bacteria (Lactobacillus sp.) and yeast (Saccharomyces sp.), and a small proportion of photosynthetic bacteria (Rhodopseudomonas sp.), actinomycetes and fermenting fungi. No macro- or microelements are contained. UGmax contains lactic acid bacteria, photosynthetic bacteria, Azotobacter, Pseudomonas, yeasts, actinomycetes and some macro- and microelements $\left(\mathrm{mg} \mathrm{dm}^{-3}\right.$ ), N-1200, P-220, K-2905, Mg-100, Na-200, Mn-0.3 (Sosnowski and Jankowski, 2013) These biofertilizers were applied in different methods, as soil and foliar application, due to the potential of biofertilizers to stimulate the natural defenses of 
potato plants. Before planting directly to the soil and during vegetation four foliar sprays, separately for each microbial product, were used at a 10-day interval. Thus, e.g. the first spraying was performed before row closure, and the third treatment was applied in full blossom. The experimental plots with biofertilizer treatments were divided into two separate parts in regard of Bioilsa application - applied or not. This fertilizer contains $12.5 \%$ organic nitrogen and $42 \%$ organic carbon, gradually releasing nitrogen and approved for organic farming (NPK 12:0:2). It was applied in the spring, 3 weeks before potato planting on selected plots at a dose of $300 \mathrm{~kg} / \mathrm{ha}$. This dose was chosen because it is mean between recommended doses, used as a standard in our tests and it was established on the basis of our experience. Three repetitions were made for each combination within one big experimental area and in each year.

\section{Determination of carbon, nitrogen and phosphates in the soil}

Soil samples for chemical analysis were collected at $30 \mathrm{~cm}$ depth (between rows of potatoes) from the experimental plots three times during each season, at the beginning of potato vegetation, at the beginning of plant drying and after harvest. The collected soil was dried in the open air and sieved through $2 \mathrm{~mm}$-thick screens, then packed in a plastic bag. Unless specified otherwise, all reagents used in this study were analytical grade. The term "water" implies de-ionized water and was used for all sample extraction, soil sample preparation and standard solutions.

The standard phosphate solutions were prepared by measuring off the appropriate volume of the $100 \mathrm{mg} \cdot \mathrm{cm}^{-3} \mathrm{o}-\mathrm{PO}_{4}{ }^{3-}$, prepared from $\mathrm{KH}_{2} \mathrm{PO}_{4}$ (Merck, Germany) standard solution into $100 \mathrm{~cm}^{3}$ volumetric flasks and filling up to the mark with water. Serial dilutions were made to obtain the standard concentrations; $0.1 ; 0.2 ; 1.0 ; 2.0 ; 5.0 ; 10.0$ and $20.0 \mathrm{mg} \cdot \mathrm{cm}^{-3}$ phosphate-P. The extraction of phosphate-P was carried out according to the Egner-Riehm method. $0.04 \mathrm{M}$ calcium lactate buffer (being acidified by hydrochloric acid up to $\mathrm{pH} 3.5-3.7$ ) was used as an extracting agent. $200 \mathrm{~cm}^{3}$ of the lactate buffer was added to the air-dried soil sample (approx. $5.000 \mathrm{~g}$ ) placed in a screwcapped $500 \mathrm{~cm}^{3}$ bottle. Activated carbon (approx. $0.20 \mathrm{~g}$ ) was added and the bottle tightly screw-capped. The mixture was then shaken for 90 min on a Heidolph REAX 20-12 shaker (15 rpm). The phosphate-P in soil extract was measured photometrically via phosphomolybdate and reduction to molybdenum blue according to PN-EN ISO 15681-1:2006. The extracted samples were analyzed using a MLE FIA-System flow injection analyzer. All pH measurements were carried out using Elmetron CP-501 pH meter. The $\mathrm{pH}$ meter was standardized with use of standard buffers (Merck). A Heidolph shaker model REAX 20-12 was used for shaking all samples while extraction of phosphate-N was carried out.

In order to determine total content of nitrogen $(\mathrm{N})$ and carbon $(\mathrm{C})$ in the soil Vario MAX CNS Element Analyzer apparatus was used. The samples were dried at $105^{\circ} \mathrm{C}$ for $60 \mathrm{~min}$ and after that sample material was weighed in an amount of $1200 \mathrm{mg}$ to reusable cups made of ceramic. The mineral soil program with max $4 \%$ content of $C$ in a sample was used. Oxygen was dosed for $120 \mathrm{~s}$ in the amount of $100 \mathrm{ml} / \mathrm{min}$ with the threshold of $\mathrm{O}_{2} 15 \%$. Sandy soil was used as a certified reference material (Soil Standard Sandy OAS Cat No. B2180 - Batch no. 133506, Elemental Microanalysis Ltd) with content $\mathrm{N}=0.7 \mathrm{~g} \mathrm{~kg}^{-1}$ and $\mathrm{C}=8.3 \mathrm{~g} \mathrm{~kg}^{-1}$. Obtained results were $\mathrm{N}=0.68 \mathrm{~g} \mathrm{~kg}^{-1}$ with recovery $97.14 \%$, and $\mathrm{C}=8.31 \mathrm{~g} \mathrm{~kg}^{-1}$ with recovery $100.12 \%$. In determination of $\mathrm{N}$ and $\mathrm{C}$ we used the so-called daily factor for $\mathrm{N}=1.0036$, for $\mathrm{C}=0.9884$, which resulted from the signs of L-glutamic acid. 


\section{Microbial analysis}

In order to determine the microbial community total numbers of bacteria, actinobacteria and fungi were evaluated. The enzymatic soil activity was assessed by content of dehydrogenases, acid and alkaline phosphatase. Sampling was performed in this same way as for chemical analysis. After that each soil sample was transported to the laboratory in PCV bags, in the fridge but not frozen.

\section{Enumeration of selected microorganisms}

The plate method was applied to determine the populations of microorganisms in soil samples collected from under the plants, at a depth of 0-20 cm. Soil microorganisms were counted on adequate agar substrate (in five replications) and expressed in colonyforming units (cfu) $\mathrm{g}^{-1}$ dry weight (DW) of soil. The total number of bacteria was determined on Merck Standard agar after 72 hours ( 3 days) of incubation at $25^{\circ} \mathrm{C}$; fungi were determined on a Martin (1950) medium after 5 days of incubation at $24^{\circ} \mathrm{C}$; actinobacteria were assessed on a Pochon medium after 5-7 days of incubation at $25^{\circ} \mathrm{C}$ (Grabińska-Łoniewska, 1999).

\section{Soil enzymatic activity}

The analyses of the enzymatic activity of soil in different experimental variants were based on the colorimetric method applied to measure the dehydrogenase activity (DHA), where 1\% TTC (triphenyl tetrazolium chloride) was used as a substrate. The measurement took place after 24-hour incubation at a temperature of $30^{\circ} \mathrm{C}$ and a wavelength of $485 \mathrm{~nm}$ and it was expressed in $\mu \mathrm{mol}$ TPF $(24 \mathrm{~h})^{-1} \mathrm{~g}^{-1} \mathrm{DM}$ of soil (Thalmann, 1968). The biochemical analyses of soil involved the determination of activities of acid (EC3.1.3.1) and alkaline (EC 3.1.3.2) phosphomonoesterases (PAC and PAL) by the method of Tabatabai and Bremner (1969). The activities were determined using as substrate disodium p-nitrophenyl phosphate tetrahydrate, after 1 hour incubation at $37^{\circ} \mathrm{C}$ at wavelength of $400 \mathrm{~nm}$. Results were converted into $\mu \mathrm{mol} \mathrm{p}$ nitrophenol PNP h${ }^{-1} \mathrm{~g}^{-1} \mathrm{DM}$ of soil.

\section{Statistics}

The changes in the microbial composition of soil and enzymatic activity were analyzed statistically. Analyzed and computed data are the means of 3 samplings per year. The results were averaged because similar changes were observed after the use of the formulations throughout the experiment. The results (mean of 2014 and 2015) were subjected to analysis of variance by means of the Statistica 9.1 program. A one-way ANOVA was carried out to determine the effects of the cultivation methods. For the F-test showing significant differences, Tukey's test (HSD) at the probability level $p=0.05$ was additionally performed to compare mean values.

\section{Results}

Dehydrogenases and phosphatases (acid and alkaline) are the most frequently investigated soil enzymes, because they exhibit noticeable reactions to stress factors (Bielińska and Mocek - Płóciniak, 2012). The analysis of variation in selected groups of soil microorganisms, such as total bacterial count, and the count of fungi and actinobacteria, is an adequate measure of soil bioactivity. The influence of different soil 
fertilizers on the microbiological state of soil was researched in the experiment. The following question arose: is the active ingredient included in the Bioilsa fertilizer strong enough to optimize the conditions of existence of bacteria improving soil properties and to acquire nutrients for agricultural production by potatoes, or is it better to apply the active ingredient with other commercially available biofertilizers, such as UGmax or soil probiotics in the form of EM. The univariate analysis of variance proved a highly significant influence $(\alpha=0.001)$ of the used fertilizers on the biochemical activity of soil under potato cultivation (Table 2).

Table 2. F test statistics and significance levels of one-way analysis of variance for the activity of enzymes and number of selected groups of microorganisms associated with fertilizers regardless of type of trade product

\begin{tabular}{c|c}
\hline Soil parameter & F test statistic \\
\hline Dehydrogenases & $10.1619^{* * *}$ \\
Acid phosphatase & $6.770^{* * *}$ \\
Alkaline phosphatase & $3.8382^{* * *}$ \\
Total number bacteria & $4.3473^{* * *}$ \\
Actinobacteria & $4.5623^{* * *}$ \\
Fungi & $2.1431^{\text {ns }}$ \\
\hline
\end{tabular}

Note: Standard deviation value was determined from five measurements.

*Statistically significant difference from control on significance level $\alpha=0.05$.

$* *$ Statistically significant difference from control on significance level $\alpha=0.01$.

$* * *$ Statistically significant difference from control on significance level $\alpha=0.001$.

DHA - dehydrogenases activity; PAC acid phosphatase activity; PAL - Alkaline phosphatase activity

The results show that the highest values of dehydrogenase activity (DHA) under the potato cultivation were observed in the variant with UGmax alone. They were much (157\%) greater than in the control variant, where no fertilizer was applied (Fig. 2).

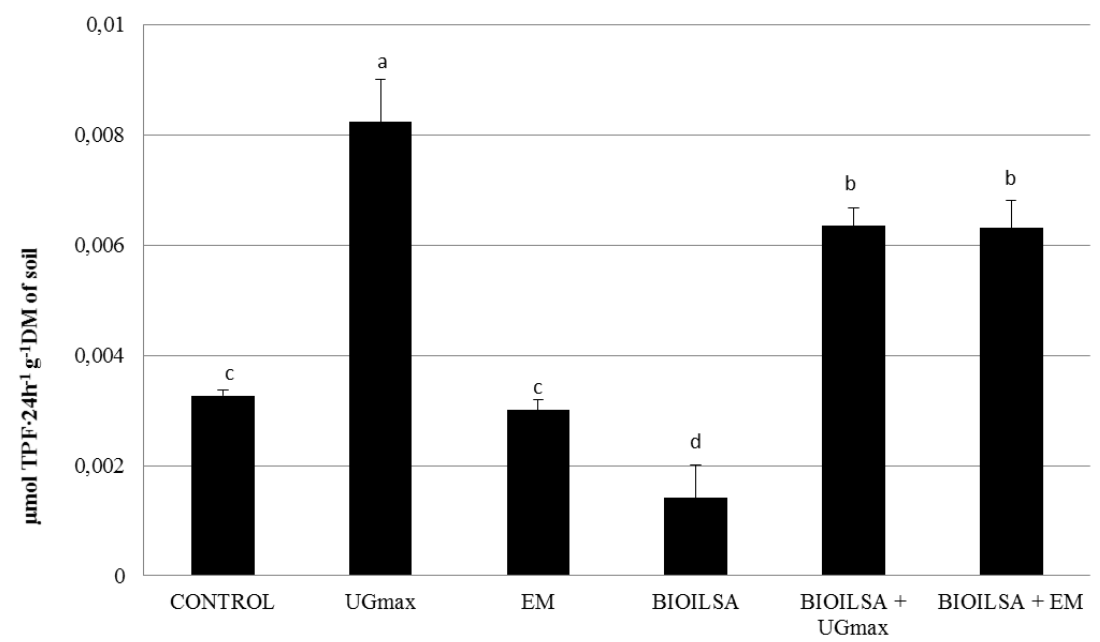

Figure 2. The effect of different of fertilizers on the dehydrogenases activity

Note: data are represented as means of five replications. Values after means are standard deviations \pm ; Means values \pm standard errors; $\mathrm{a}, \mathrm{b}, \mathrm{c}, \mathrm{d}-$ homogenous groups according to Tuckey's test; different letters denote statistical differences at level $\alpha=0.05 ; \mathrm{n}=5$ 
The lowest dehydrogenase activity was observed in the variant with the Bioilsa fertilizer; it was $43 \%$ lower than in the control combination, where the activity of this enzyme was similar as in the combination with the probiotic formulation EM (Fig. 2).

The next indicator, acid and alkaline phosphatases activity, was statistically significantly higher $(\mathrm{p}=0.001)$ in the non-fertilized (control) variant compared with the other combinations. No differences in activity of phosphatase in relation to sole application of UGmax or probiotic EM were observed and it was higher than in variants with Bioilsa fertilizer. On the other hand, in the variant where Bioilsa and UGmax fertilizers had been applied simultaneously the lowest value of acid and alkaline phosphatase activity was observed (Fig. 3 and 4).

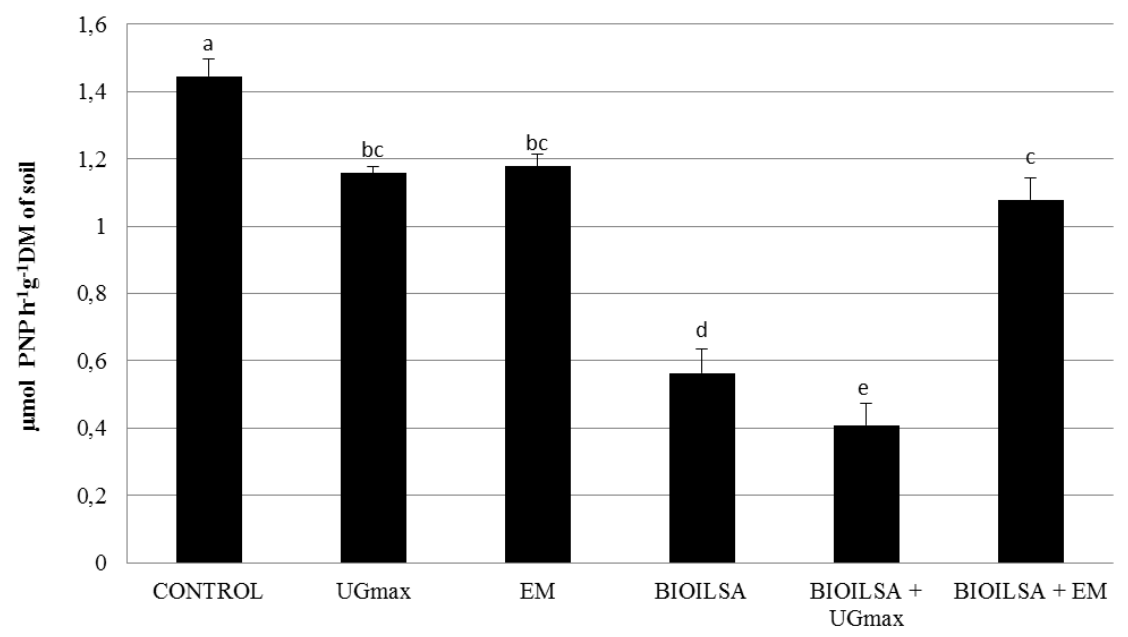

Figure 3. The effect of different of fertilizers on the acid phosphatase activity

Note: data are represented as means of five replications. Values after means are standard deviations \pm ; Means values \pm standard errors; a, b, c, d, e - homogenous groups according to Tuckey's test; different letters denote statistical differences at level $\alpha=0.05 ; \mathrm{n}=5$

Generally, in variants with application of Bioilsa higher values of nitrogen, carbon and phosphorus were noted compared to variants without this organic fertilizer. The highest value $\left(0.750 \mathrm{~g} \mathrm{~kg}^{-1}\right)$ of nitrogen was observed in variants with Bioilsa and without biofertilizers, but in combination without Bioilsa addition the biofertilizers can increase the content of nitrogen in the soil. However, it was not statistically confirmed (Table 3).

Table 3. The content of the nitrogen, the carbon and phosphorus in the soil

\begin{tabular}{l|c|c|c}
\hline \multirow{2}{*}{$\begin{array}{l}\text { Plots with different type of } \\
\text { fertilizers }\end{array}$} & \multicolumn{3}{|c}{ Total content/whole season, average value } \\
\cline { 2 - 4 } & $\begin{array}{c}\text { Nitrogen }(\mathbf{N}) \mathbf{g} \\
\mathbf{~ k g}^{-1}\end{array}$ & $\begin{array}{c}\text { Phosphorus } \\
\mathbf{P}_{\mathbf{2}} \mathbf{O}_{\mathbf{5}} \mathbf{~ m g}(\mathbf{1 0 0 g})^{-\mathbf{1}} \\
\mathbf{a . d . m}\end{array}$ & $\begin{array}{c}\text { Carbon }(\mathbf{C}) \\
\mathbf{k g}^{-1}\end{array}$ \\
\hline Bioilsa. non - biofertilizer & 0.750 & 28 & 7.195 \\
Bioilsa. with UG max & 0.693 & 28.6 & 6.601 \\
Bioilsa. with EM & 0.696 & 45.7 & 6.550 \\
Average for plots with Bioilsa & $\mathbf{0 . 7 2 1}$ & $\mathbf{3 4 . 1}$ & $\mathbf{6 . 7 8 2}$ \\
Non Bioilsa. with UGmax & 0.721 & 30.8 & 6.703 \\
\hline
\end{tabular}




\begin{tabular}{l|c|c|c}
\hline Non Bioilsa. with EM & 0.713 & 28.2 & 6.593 \\
Non Bioilsa. non - biofertlizer & 0.705 & 25.5 & 6.770 \\
$\begin{array}{l}\text { Average for plots without } \\
\text { Bioilsa }\end{array}$ & $\mathbf{0 . 7 1 3}$ & $\mathbf{2 8 . 1 6}$ & $\mathbf{6 . 6 8 8}$ \\
\hline
\end{tabular}

Note. a.d.m - air dried mass, - only indicative values are noted, with no statistical tests, samplings were taken three times within whole season

After application of the nitrogen organic fertilizer (Bioilsa) the average content of the nitrogen was higher $\left(0.721 \mathrm{~g} \mathrm{~kg}^{-1}\right)$ compared to plots not fertilized with Bioilsa $(0.713 \mathrm{~g}$ $\left.\mathrm{kg}^{-1}\right)$; the content of the carbon was $6.78 \mathrm{~g} \mathrm{~kg}^{-1}$ in relation to plot not fertilized with Bioilsa $\left(6.68 \mathrm{~g} \mathrm{~kg}^{-1}\right)$. The value of the last evaluated element, phosphorus, was $34.1 \mathrm{mg}$ compared to non-fertilized $28.1 \mathrm{mg}$. Fertilization with Bioilsa in various modes influenced the parameters of chemical properties (Table 3).

The phosphorus content was higher in the soil after Bioilsa application; it may have caused that activity of phosphatases was lower compared to results obtained for samples collected from non-Bioilsa plots (Fig. 3 and 4). There were analogical observations about alkaline phosphatase (Fig. 4).

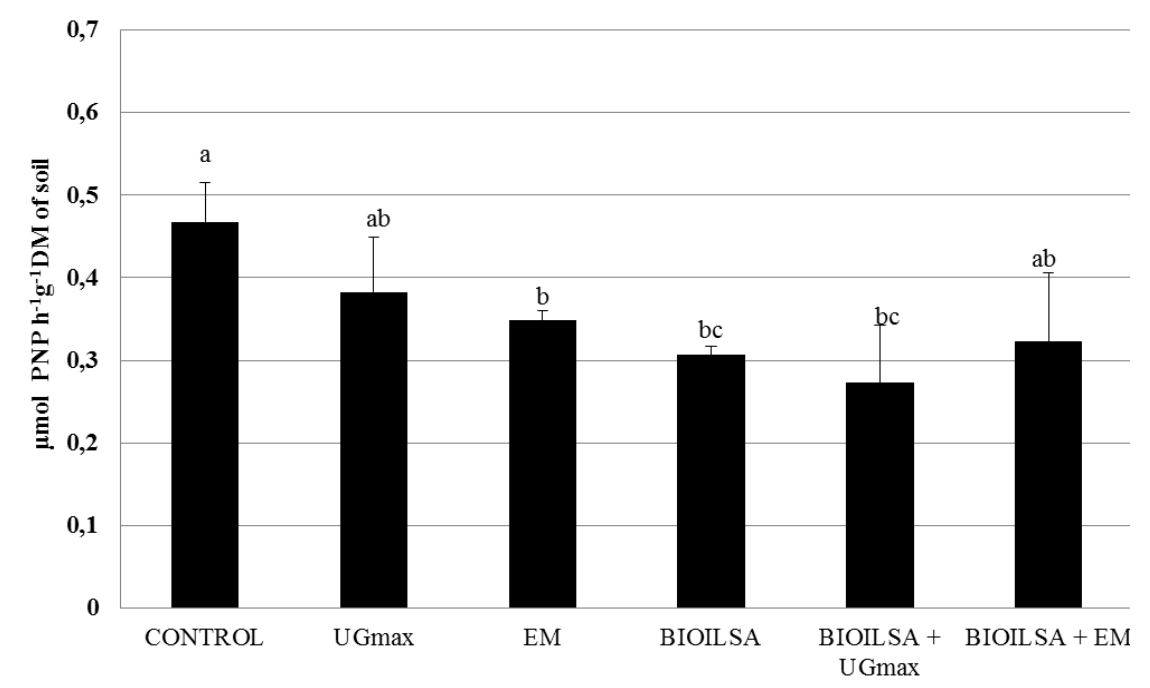

Figure 4. The effect of different of fertilizers on the alkaline phosphatase activity

Note: data are represented as means of five replications. Values after means are standard deviations \pm ; Means values \pm standard errors; $\mathrm{a}, \mathrm{b}, \mathrm{c}-$ homogenous groups according to Tuckey's test; different letters denote statistical differences at level $\alpha=0.05 ; \mathrm{n}=5$

The results of the influence of all used fertilizers applied to the soil under potatoes on the number of selected groups of soil microorganisms point to a highly significant influence $(\alpha=0.001)$ on the changes in the number of total bacteria and actinobacteria in soil. This effect was confirmed by statistical tests (Table 2). This correlation was not observed in fungi (Table 2). The total number of bacteria and actinobacteria was the highest in EM variants not fertilized with Bioilsa. In variants with Bioilsa application the microbial products had an impact on increase of the population of these microorganisms (Fig. 5 and 6). 


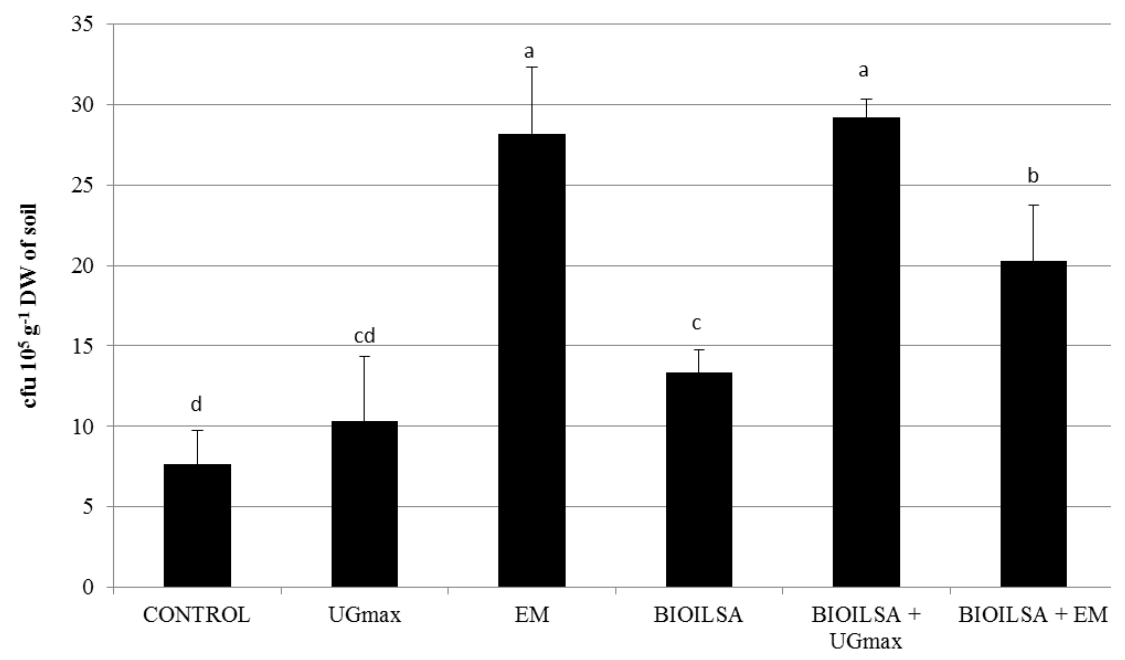

Figure 5. The effect of different of fertilizers on the total number bacteria

Note: data are represented as means of five replications. Values after means are standard deviations \pm ; Means values \pm standard errors; $\mathrm{a}, \mathrm{b}, \mathrm{c}, \mathrm{d}$ - homogenous groups according to Tuckey's test; different letters denote statistical differences at level $\alpha=0.05 ; n=5$

According to Szember (2001), the latter group belongs to a so-called ecological group of microorganisms, which indicates soil fertility. It is noteworthy that the formulations applied to the soil contained certain amounts of macroelements (UGmax, Bioilsa), which may have increased the count of this group of microorganisms. There were similar results in the study by Swędrzyńska et al. (2011), who reported that there was a large increase in the count of actinobacteria when microbial formulations were applied to soil under perennial ryegrass. It is noteworthy that in our study the greatest increase in the count of these microorganisms was observed when probiotic EM had been applied (Fig. 5 and 6 ).

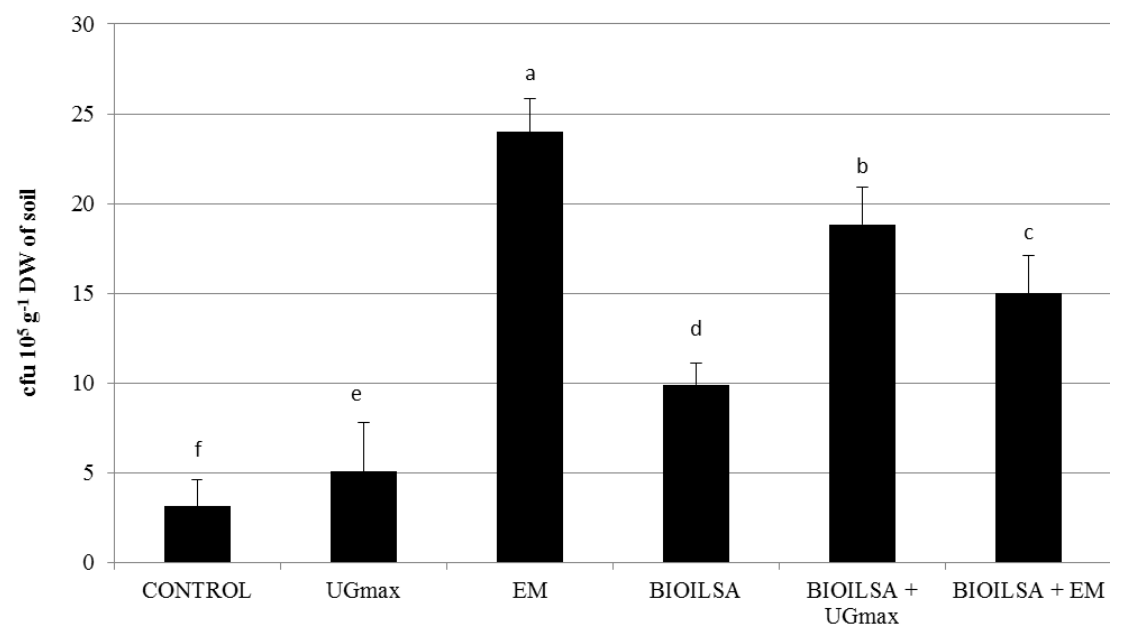

Figure 6. The effect of different of fertilizers on the Actinobacteria

Note: data are represented as means of five replications. Values after means are standard deviations \pm ; Means values \pm standard errors; a, b, c, d, e, f- homogenous groups according to Tuckey's test; different letters denote statistical differences at level $\alpha=0.05 ; n=5$ 
The increase in the total count of bacteria and actinobacteria in these variants can be explained in two ways. The microorganisms supplied in the formulations may have been a perfect source of carbon for autochthonous bacteria colonizing the soil environment. On the other hand, the fertilizing formulation with macro-, microelements and microorganisms may have promoted the availability of nutrients and in consequence increased the count of these groups of microorganisms. There were similar correlations observed in fungi, but they were not statistically significant (Fig. 7).

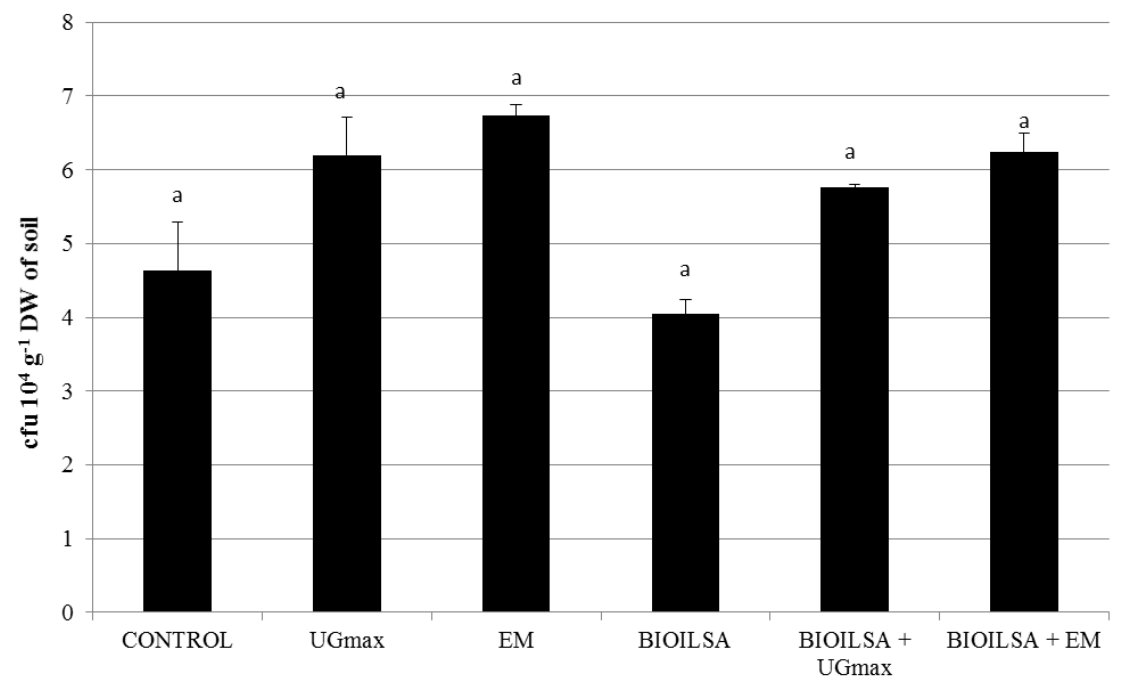

Figure 7. The effect of different of fertilizers on molds (the fungi)

Note: data are represented as means of five replications. Values after means are standard deviations \pm ; Means values \pm standard errors; a - homogenous groups according to Tuckey's test; the same letter denote not statistical differences at level $\alpha=0.05 ; n=5$

\section{Discussion}

According to Brzezińska and Włodarczyk (2005), DHA in the soil is an indicator of the intensity of respiratory metabolism of microorganisms, especially eubacteria and actinobacteria. The analysis of the activity of these enzymes provides information about the content of organic matter or fertility of the substrate. We can conclude that increased dehydrogenase activity in the variant where UGmax was applied to the soil was primarily caused by additional microorganisms included in this product as well as macro- and microelements contained in this fertilizer.

When measuring acid phosphatase activity it is necessary to remember that the amount of this enzyme in the soil environment is strongly influenced by plants, whose roots secrete considerable amounts of it, especially if they do not receive a sufficient supply of phosphorus (Burns, 1985; Dahm et al., 1986; Żebrowska and Ciereszko, 2009). The high concentration of acid phosphatase in the control combination (where fertilization had not been applied) may have been the plants' response to a lesser supply of phosphorus in the soil environment. Many authors mention the fact that if there is a deficit of absorbable phosphorus in soil, plants' roots secrete higher amounts of phosphatase catalyzing hydrolysis of the C-O-P bond in organic phosphorus compounds (Schneider et al., 2001).

It is known that if phosphorus content is low, the activity of these enzymes is higher. According to Bielińska and Mocek-Płóciniak (2012), their long-term observations 
proved that the acid phosphatase enzyme was strictly correlated with the physiochemical properties of soil. We noted statistically significantly low activity of acid phosphatase in the variants where the nitrogen organic fertilizing formulation had been applied. This indicates that microbial formulations provide plants adequate amounts of phosphorus. Tarafdar and Rao (1990) reported a correlation between the uptake of phosphorus by plants, yield and acid phosphatase activity.

Microorganisms are attributed a significant role in the functioning of the soil ecosystem (Ahemad et al., 2009). They play a key role in controlling the reactions which are necessary to maintain soil fertility and structure. The soil is also characterized by bioactivity, which is indirectly influenced by soil microorganisms and the enzymes they secrete (Kieliszewska-Rokicka, 2001). The existence of soil microorganisms is not only limited to providing access to mineral compounds. They cause favorable transformations in soil, optimizing the living environment, growth and yield of plants. Positive effects on yield and plant healthiness after application of the same formulations were presented in the paper of Kowalska (2016). Apart from that, they participate in transformation of soil organic matter and are decisive to soil structure and its $\mathrm{pH}$. They produce numerous bioactive substances in soil. Soil microorganisms detoxify many chemical compounds which are harmful to other organisms living in this environment, and they eliminate pathogenic organisms (Niewiadomska, 2013).

\section{Conclusion}

The research has shown that the highest values of dehydrogenase activity under the potato cultivation were observed in the variants with UGmax. Application of all tested fertilizers stimulated the availability of phosphorus to plants in the soil, because measurements showed the lowest phosphatase activity in soils collected from plots fertilized with Bioilsa. The positive effect of the different fertilizers UGmax and probiotic EM applied in the experiment on potatoes was also observed in the groups of soil microorganisms under study. Their number was greater than in the variant not fertilized with Bioilsa. When Bioilsa formulation was applied, the microbial products had a stimulating effect on the enzymatic activity or number of microorganisms. Such correlations were not observed only for the acid phosphatase activity after the application of UGmax. From the microbiological point of view the research findings should be regarded as promising. Our research indicated that biofertilizers can activate the microbial and enzymatic activity of the soil after intensive agriculture production and can neutralize the negative impact on these parameters of nitrogen fertilizer. We recommend continuing studies to confirm their effectiveness and usefulness in sustainable agricultural production.

Acknowledgements. This study was financed by the Ministry of Agriculture and Rural Development of Poland within the funding of the research for organic farming. Authors thank also to Dr. Marcin Grobela and Dr. Rafał Motała for making of the chemical analyses of the soil sample.

\section{REFERENCES}

[1] Abd El-Malek, A. A. (2005): Biofertilization usage of producing environmentally safe potato crop. - M.Sc Thesis, Inst. of Environment Studies and Resources., Fac. Agric., Ain Shams Univ., Cairo, Egypt. 
[2] Abou El-Yazied, A. M., Sellim, A. S. M. (2007): Effect of reducing N, P mineral fertilization levels combined with bio fertilizer on growth, yield and tuber quality of potato plants. - Journal of Agriculture Science, Mansoura Univ., Mansoura, Egypt. 32(4): 2701-2726.

[3] Araújo, A. S. F., Leite, L. F. C., Santos, V. B., Carneiro, R. F. V. (2009): Soil Microbial Activity in Conventional and Organic Agricultural Systems. - Sustainability 1: 268-276; doi: $10.3390 /$ su1020268

[4] Ahemad, M., Zaidi, A., Khan, S., Oves, M. (2009): Factors affecting the variation of microbial communities in different agro ecosystems. - In: Microbial Strategies for crop improvement. Springer, Berlin Heidelberg, 301.

[6] Amaral, F., Abelho, M. (2016): Effects of agricultural practices on soil and microbial biomass carbon, nitrogen and phosphorus content: a preliminary case study. - Web Ecology 16: 3-5. doi:10.5194/we-16-3-2016 www.web-ecol.net/16/3/2016/

[7] Anonim (2007): Council Regulation (EC) No. 834/2007 of 28 June 2007 on organic production and labelling of organic products and repealing Regulation (EEC) No 2092/91

[8] Bielińska, E. J., Mocek-Płóciniak, A. (2012): Impact of the tillage system on the soil enzymatic activity. - Archives of Environmental Protection 38 (1): 75-82.

[9] Brzezińska, M., Włodarczyk, T. (2005): Transformations in intracellular redox enzymes (oxidoreductase). - Acta Agrophysica, Dissertations and Monographs (3): 11-26. (in Polish)

[10] Burns, R. G. (1985): The rhizosphere: microbial and enzymatic gradients and prospects for manipulation. - Pedologie 35 (3): 283-295.

[11] Dahm, H., Różycki, H., Strzelczyk, E. (1986): Bacteria and actinomycetes of soil and root zone soil in forest trees. - Progress in Microbiology 25: 103-120.

[12] Długosz, J., Orzechowski, M., Piotrowska, A., Smólczyński, S., Bogdanowicz, P. (2010): Changes in some soil properties under the influence of the soil fertilizer UGmax. Proceedings of the conference and the workshop - Seed growing and potato protection, 32-34. (in Polish)

[13] Grabińska-Łoniewska, A. (1999): Laboratory classes in general microbiology. - Pub.: University of Technology, Warsaw. (in Polish)

[14] Kallenbach, C., Grandy, A. S. (2011): Controls over soil microbial biomass responses to carbon amendments in agricultural systems: A meta-analysis. - Agriculture of Ecosystem Environmental 144: 241-252.

[15] Kieliszewska-Rokicka, B. (2001): Soil enzymes and their significance in the study of biological activity of the soil. - In: Dahm, H., Pokojska-Burdziej, A., Marszałek, A. (ed.) The microorganisms of the soil environment, 37-47.

[16] Kowalska, J. (2016): Effect of fertilization and microbiological bio-stimulators on healthiness and yield of organic potato. - Progress in Plant Protection, 56: 230-235.

[17] Le Guillou, G., Scharpé, A. (2001): Organic Farming: Guide to Community Rules. European Commission, Luxembourg, 28.

[18] Mäder, P., Fliebbach, A., Dubois, D., Gunst, L., Fried, P., Niggli, U. (2002): Soil fertility and biodiversity in organic farming. - Science 296: 1694-1697. DOI: 10.1126/science.1071148 Downloaded from www.sciencemag.org on December 4, 2006.

[19] Martin, J. P. (1950): Use of acid, rose Bengal and streptomycin in the plate method for estimating soil fungi. - Soil Science 15: 215.

[20] Martyniuk, S. (2011): Effective and ineffective microbial preparations used in plant protection and production and methods of their evaluation. - Progress Microbiology 50 (4): 321-328. (in Polish)

[21] Martyniuk, S., Księżak, J. (2011): Assessment of pseudo-microbial bio-preparations used in crop production. - Polish Journal of Agronomy 6:27-33. (in Polish)

[22] Mayer, J., Scheid, S., Oberholzer, H. R. (2008): How effective are 'Effective Microorganisms'? Results from an organic farming field experiment. 16th IFOAM 
Organic World Congress, Modena, Italy, June 16-20, 2008. Archived at http://orgprints.org/14838

[23] Mayer, J., Scheid, S., Widmer, F., Fließbach, A., Oberholzer, H. R. (2010): How effective are 'Effective microorganisms ${ }^{\circledR}(\mathrm{EM})$ '? Results from a field study in temperate climate. - Applied soil ecology 46: 230-239.

[24] Niewiadomska, A. (2013): Assessment of the impact of PRP SOL fertiliser and coinoculation on the process diazotophy, biological and chemical properties of soi land crop conditio under clover and alfalfa cultivation. - Pub. University of Life Sciences in Poznan. pp106. (in Polish)

[25] Niewiadomska, A., Sulewska, H., Wolna - Maruwka, A., Klama, J. (2010): Effect of organic fertilization on development of proteolytic bacteria and activity of proteases in the soil for cultivation of maize (Zea Mays L.) - Archives of Environmental Protection 36 (2): 47.

[26] Nortcliff, S. (2002). Standardization of soil quality attributes. - Agriculture ecosystem and environmental. 88: 161-168.

[27] Sangakkara, U. R., Wijesinghe, D. B., Attana Yake, K. B. (2011): Soil quality Phaseolus bean yields as affected by organic matter and EM in degraded tropical soil. - In: 16th IFOAM Organic World Congress, Modena, Italy, 102-105. vo1. 1. Organic crop protection, 835.

[28] Santos, V.B., Araújo, A.S.F., Leite, L.F.C., Nunes, L. A. P. L., Melo, W.J. (2012): Soil microbial biomass and organic matter fractions during transition from conventional to organic farming systems.- Geoderma 170: 227-231.

[29] Schenck zu Schweinsberg-Mickan, M., Müller, M. T. (2009): Impact of effective microorganisms and other biofertilizers on soil microbial characteristics, organic-matter decomposition and plant growth. - Journal of Plant Nutrition and Soil Science 172: 704712.

[30] Shneider, K., Turion, M. B., Grierson, P. E., Gallardo, J. E. (2001): Phosphate activity, microbial phosphorus, andfine roothin forest soils in the Sierrade Gata western central Spain. - Biology and Fertility of Soils 34: 151-155.

[31] Sosnowski, J., Jankowski, K. (2013): Effect of soil fertilizer UGmax on feed value of some grass species depending on their cuts. - Acta Scientiarum Polonorum. Agricultura 12 (1): $35-44$

[32] Swędrzyńska, D., Zielewicz, W., Swędrzyński, A., Niewiadomska, A. (2011): Effect of fertilizers and preparations to improve the biological properties of the soil used in the cultivation of perennial ryegrass, on the size of the population of selected groups of microorganisms. - Progress Agricultural Sciences 564: 237-247. (in Polish)

[33] Szember, A. (2001): The outline of agricultural microbiology. - Pub.: Agriculture Academy Lublin, 215 (in Polish)

[34] Tabatabai, M. A., Bremner, J. (1969): Use of P-nitrophenyl phosphate for assays of soil phosphatase activity. - Soil biology and biochemistry. 1: 301.

[35] Tarafdar, J. C., Rao, A. V. (1990): Effect of diffrent herbicides on enzyme activity in controlling Leeds in wheat crop. - Pesticides. 20: 46-49.

[36] Thalmann, A. (1968): Zur methodik der bestimmung der dehydrogenase aktivität in boden mittels triphenyltetrazoliumchlorid (TTC). - Landwirtschaft Forsh. 21: 3. (in German).

[37] Tian, Y., Zhang, X., Liu, J., Chen, Q., Gao, L. (2009): Microbial properties of rhizosphere soils as affected by rotation grafing and soil sterilization in intensive vegetable production systems. - Scientia horticulturae 123: 139.

[38] Trawczyński, C., Bogdanowicz, P. (2007): The use of soil fertilizer UGmax in aspect of organic cultivation of potato. - Journal of Research and Applications in Agricultural Engineering 52 (4): 94-97. 
[39] Workneh, F., van Bruggen, A. H. C. (1994): Suppression of corky root of tomatoes in soils from organic farms associated with soil microbial activity and nitrogen status of soil and tomato tissue. - Phytopathology 84: 688-694.

[40] Yassin, A, M. (2002): Application of biofertilizer in potato production. - Ph.D. Thesis Fac. Agric. Ain-Shams Univ., Cairo, Egypt.

[41] Zarzecka, K., Gugała, M., Milewska, A. (2011): Effect of soil fertilizer UGmax on potato yield and plant health. - Progress in Plant Protection 51 (1): 153-157. (in Polish)

[42] Żebrowska, E., Ciereszko, I. (2009): Participation of acid phosphatases in phosphorus management of plant cells. - Progress of Cell Biology 36 (4): 583-599 (in Polish). 